\title{
Determinants of online trust and their impact on online purchase intention
}

\author{
Dr Kaouher Kooli* Dr Kaouther Ben Mansour**, and Rizky Utama*** \\ *: Dr Kaouther Kooli, Lecturer in Marketing, Business school, Bournemouth University, \\ Talbot Campus, Poole, Dorset, BH12 5BB. Email : kkooli@ bournemouth.ac.uk \\ ** Dr Kaouther Ben Mansour, Assistant professor in Marketing, IHEC-Carthage, Tunisia. \\ Email: benmansour_kaouther@yahoo.fr \\ ***: Rizky Utama, Strategic communication analyst at Central Bank of Indonesia, \\ Email: utama.rizky@gmail.com
}

\begin{abstract}
Abundant literature has examined online trust. However the different approaches were scarcely integrated to address the determinants of online trust and their impacts on online purchase intention. An integrative approach to online trust is adopted in this paper. A survey is carried out on a sample of 401 online consumers in Indonesia. The findings show that purchase intention is significantly influenced by online trust. Besides, there is significant impact of personality based trust (benevolence, integrity, credibility), cognitive based trust (reputation and cost benefit calculation) and institutional based trust (situation normality) on online trust.
\end{abstract}

Keywords: Online trust, Personality based trust, Cognitive based trust, Institutional based trust, Purchase intention. 


\section{Introduction}

The development of E-commerce is challenged by several factors related both supply and demand sides. Although businesses widely developed transactional websites, consumers' online shopping didn't reach, yet, the level of managers' expectations (Isaac and Volle, 2013). So far, the demand has been behind the offer in terms of online shopping adoption. For businesses, this generates a weak return on investment and a deferred profitability.

It has been demonstrated that consumers browse e-vendor websites to seek information but very few progress to the buying stage in their decision process (Chen and Barnes, 2007; Johnson, 2007). Abundant literature looked at the factors hindering consumers' adoption of online shopping (Jiyeon and Forsythe, 2010; Grewal et al., 2004; Schoenbachler, D.D. and Gordon, G.L., 2002). Consumers' lack of trust in e-vendor has been shown to be an important factor influencing online shopping (Chen and Barnes, 2007, Bhattacherjee, 2002; (Koufaris and Hampton-Sosa, 2004). The transaction intangibility aspects as well as security and privacy concerns generate consumers' distrust in online shopping (Isaac and Volle, 2013).

To develop e-commerce, e-businesses have to fully understand the determinants of online trust and their impacts on online purchasing. Trust was found to significantly influence online purchase intention (Isaac and Volle, 2008; Kim et al., 2008).

However, different approaches to online trust were suggested in the literature. However, they were scarcely integrated to explain consequences of online trust on purchase intention. This paper addresses this gap by adopting an integrative approach to online trust determinants and by explaining its consequences on online purchase intention.

Most of the literature about online trust has been developed in Western economies. Little is known about trust in emergent countries. This research is conducted in Indonesia which is considered as an emergent market.

The research objectives are (1) to design a framework of the cause and effect relationship between online trust determinants, online trust, and online purchase intention, (2) to test and validate this framework using a sample of Indonesian consumers shopping at kaskus.com.

\section{Theoretical background}

Trust is essential in Business to Business and Business to Consumer relationships (Rosseau et $a l .$, 1998, and Doney and Cannon, 1997, Doney et al., 2007). In B2B marketing, Doney et al. (2007, p: 13) claimed that trust has a positive influence on loyalty, commitment and expanded business opportunities. Trust also enables companies to build long term relationships with end consumers and generate their loyalty (Fletcher and Peters, 1997 and Selnes, 1998). 
Definitions and conceptualization of trust vary with disciplines. Psychologists view trust as a personal trait, sociologists consider it as a social construct, and economists see it as an economic choice mechanism (McKnight and Chervany, 2002).

In social psychology, Rousseau et al. (1998) define trust, firstly, as a perception about others' attributes and, secondly, as a related willingness to become vulnerable to others". With greater trust, people can resolve their uncertainty regarding the motives, intentions, and prospective actions of others on whom they depend (Kramer, 1999), as well as save money and effort, because trust reduces monitoring and legal contract costs (Fortin et al., 2002).

Drawing on literature in social psychology, and marketing, Moorman et al. (1993, p.82) define trust as "the willingness to rely on an exchange partner in whom one has confidence". Morgan and Hunt (1994) defined trust as something that arises when one group or individual believes in the reliability and integrity of his exchange partner.

Other approaches to trust were suggested. Mayer et al. (1995, p.172) defined trust as "the willingness of a party to be vulnerable to the actions of another party based on the expectation that the other will perform a particular action important to the trustor, irrespective of the ability to monitor or control that other party”. Moreover, Gefen (2000, p.726) defined trust as "the confidence a person has in his or her favorable expectations of what other people will do, based, in many cases, on previous inter-actions"

With regards to consumer trust there are two perspectives in the study of trust. Firstly, individual trust can be related to the personality characteristics. Lewicki and Bunker (1995) conceptualized individual trust is as a belief; expectancy or feeling that is deeply rooted in the personality, with its origins in the individual early psychological development. Individual trust can be also related to individual experiences such as satisfaction of interpersonal exchange (Sheppard and Sherman, 1998). Secondly, societal trust is related to the relationship between individuals and institutions. Trustiness can be built based on social environment recommendations to purchase some products (Buttler, 1991).

Selnes (1998) mentioned that there are four antecedent of trust in B2C context:

competency of the company or the service provider, communication of the company to provide timely and trustworthy information to the consumer, commitment to satisfy the customer and conflict handling. In addition, Selnes (1998) also mentioned that customer satisfaction has a significant impact on customer' trust.

Moreover, Moorman et al., (1993) mentioned that trust depends on the quality of the relationship between individuals, individuals and institutions and between institutions. Crosby 
et al. (1991) and Parasuraman et al., (1985) added that credibility and satisfaction of the quality of the relationship can lead to trust which can lead to behavioural intention (Mcknight et al., 2002). In marketing literature, confidence and reliability were shown as essential antecedents of trust (Matos and Rossi, 2008). In online environment, the absence of trust is one of the most important obstacles of accepting online trade (Isaac and Volle, 2008). The following section develops a conceptual framework of the antecedents of online trust and its consequences on purchase intention.

\section{Conceptual model}

Recent literature indicated that trust has a critical impact on users' willingness to engage in online exchanges of money and sensitive personal information (Al-smadi, 2012; Nasri, 2011; Agarwal et al., 2009; Ozdemir and Hoecht, 2008; Wang et al., 2003; Suh and Han, 2002; Friedman et al., 2000). According to Grewal et al. (2004), consumers might not use ecommerce because they lack trust in Internet businesses. Besides, the lack of trust in online transactions and Web vendors represents an important obstacle to the market penetration of echannels (Liu et al., 2004). It is essential for businesses to comprehend online trust determinants and their consequences on online purchase intention. Typologies of trust were suggested in both B2B context and B2C (Hofstede, 2010; Gulati and Sytch, 2008; Mcknight et al., 2002). McKnight and Chervany (2001) suggested four concepts: disposition to trust, institution-based trust, trusting belief and trusting intention. McKnight et al. (2002) focused on the web vendor to define trust as beliefs and intentions or willingness to rely on another party. Li et al. (2008) and Brown et al., (2004) suggested a personality based conceptualization of online trust.

Li et al. (2008) and Meyerson et al. (1996) added that trust can be cognitive based and suggest two dimensions: reputation of the web vendor (Li et al. 2008, Mcknight et al. 2002 and Gefen et al. 2003) and calculative trust (Li et al. 2008). Moreover, Yoon (2002) demonstrated that website properties factor is a significant antecedent to online trust and that assurance of transaction security and personal variables both play a role in enhancing web-site trust. Antecedents of online trust can be classified in three types that differently contribute to it $(\mathrm{Li}$ et al., 2008 and Wang, 2010): the cognition-based trust, , the institution-based trust and the personality-based trust. 


\section{Personality based trust}

Doney and Cannon (1997) defined trust as the perceived credibility and benevolence of a target of trust. Mcknight and al., (2002) added a third dimension of trust, which is the integrity. These dimensions are widely accepted and used in research (Bhattachjee, 2002; Gefen et al., 2003). The first dimension of trust, perceived credibility, is the extent to which one partner believes that the other partner has the required expertise to perform the job (Denis, 2007; Chouk et Perrien, 2003; Gefen, 2002; Morgan et Hunt, 1994) effectively and reliably (Ganesan 1994). Then, trust based on a partner's expertise and reliability focuses on the objective credibility of an exchange partner: expectancy that the word or written statement of the partner can be relied on (Wang et Emurian, 2005). Wang and Emurian (2005) refer to the belief that the electronic supplier has the required knowledge to do his job effectively. The second dimension of trust, benevolence, is the extent to which one partner is genuinely interested in the welfare of the other and is motivated by the search for common gain (Denis, 2009). It reflects the belief that the supplier wishes well to the user despite its own profits (Gefen 2002; Ganesan 1994). Benevolence is thus the belief that the electronic merchant is interested in user interests (Wang and Emurian 2005; Chouk and Perrien, 2004; Chen and Dhillon; 2003; Bhattacherjee, 2002). The third dimension of trust, integrity, is the belief that the other party accepts the honesty and the respect of promises and commitments (Isaac and Volle, 2008; Chouk and Perrien, 2004; Gefen, 2002). The perceived integrity is the confidence that the merchant-mail do not exploit the vulnerability and that it will honor its commitment by promising to protect the security of transactions and the confidentiality of information (Jannouri et Gharbi, 2008; Wang and Emurian 2005; Chouk Perrien and 2003; Bhattacherjee 2002). Based on the above discussion, we posit:

\section{H1: Benevolence in personality based trust is positively related to Online Trust \\ H2: Integrity in personality based trust is positively related to Online Trust \\ H3: Credibility in personality based trust is positively related to Online Trust}

\section{Cognitive Based Trust}

Cognitive based trust is built through people use of their common knowledge - own mind or asking relatives or friends- when they want to purchase online a particular product (Li et al., 2008). Cognition-based trust is a moderator in the relationship between cognitive conflict and decision outcomes(Parayitama and Dooleyb, 2009). It arises from first impression rather than experiential personal interactions (Meyerson et al., 1996). Based on this first impression, Li et al. (2008), and Mcknight et al. (2002) and Jarvenpa et al. (1999) emphasised reputation of 
web vendor as being an antecedent factors of cognitive based. Reputation is the extent to which buyers believe that the selling organization is honest and concerned about its customers (Doney and Cannon, 1997). Organization's reputation and size were found to contribute to trust (Anderson and Weitz, 1989; Ganesan, 1994; Doney and Cannon, 1997). Mcknight et al., (1998) explained that reputation categorization can be known through second hand information i.e. relatives and friends. Sabater and Sierrathe (2005) demonstrated that the main sources of information used by the trust and reputation models are direct experiences and information from third party agents. Quelch and Klein (1996) and Lohse and Spiller (1998) speculate that the reputation of the store will influence perceptions of the website. In addition, Powel (1996) also mentioned that reputation may reflect to the professional competence. Jarvenpaa et al. (1999) added that reputation of a website has become the most significant antecedent of cross cultural trust building in consumer. In addition, Gefen (2000) explained that when people lack of information and experience about particular vendor, the cognitive process will be running based on second hand knowledge and impressions. Doney et al. (1991) added calculative or cost and benefit calculation dimensions as an antecedent of cognitive based trust. Furthermore, Shapirro et al. (1992) stated that calculative based trust is driven by economic principles, when people shaped by their rational assessment of the cost and benefits of another party cheating or cooperating in the relationship. Moreover, people tend to trust when the trustee is thought to have nothing to gain, or the cost overwhelms the benefit, from being untrustworthy (Shapiro et al., 1992). Paul and McDaniel (2004) evaluated calculative trust in an initial interpersonal trust context and argued that as long as the trustor is vulnerable to the non-performance of the trustee, calculative trust is effective. Based on this discussion, we posit:

H4: Reputation in cognitive based trust is positively related to Online Trust H5: Cost/Benefit Calculation is positively related to Online Trust

\section{Institutional Based Trust}

Bachmann and Inkpen (2011) claimed that institutions can be an important and efficient facilitators of trust that develop through legal provision, corporate reputation, certification exchange partners and community norms, structures and procedures. Besides, the authors added that institutions matter differently according to stages of a trustor-trustee relationship, level of assets specificity, level of maturity of the business and the rapidity of decision making requirement. 
Mcknight et al. (2003, p. 339) defined Institutional based trust as "the belief that needed structural conditions are present (e.g., in the Internet) to enhance the probability of achieving a successful outcome in an endeavor like e-commerce". According to Mcknight et al. (2003) there are two dimensions of institution trust based which are: structural assurance and situational normality. Trust is supported by institutions through the use of guarantees, regulations, promises, legal recourse, or other procedures are in place to promote success structures that create an environment that feels safe and secure to participants (Bachmann and Inkpen 2011, Shapiro, 1987; Zucker, 1986). Corbitt et al. (2003) added that the quality of web vendor developed through usefulness, timeliness and advance of the website can build trust. Selnes (1998) mentioned that quality of web vendor is achieved through giving correct and accurate information about products or other information about company also being part of quality of web vendor. Quality of web vendor influences trust beliefs (Mcknight et al. 2002). Moreover, situation Normality is another dimension of institutional based trust which means that a people will believe that the situation they face is normal, in or in proper order because it is favorable (Baier, 1986). In addition, with regards to the e-commerce, people who step in this situation will feel that the internet environment is appropriate well ordered, and favorable for doing transaction (Mcknight et al., 2003). Moreover, online trust has been found to significantly influence purchase intention (Yoon, 2002; Kim et al., 2008). Based on this discussion, we posit:

H6: Assurance positively related to online Trust

H7: Quality is positively related to online Trust

H8: Situation Normality is positively related to online Trust

H9: Online Trust is positively related to Purchase Intention 


\section{Conceptual model}

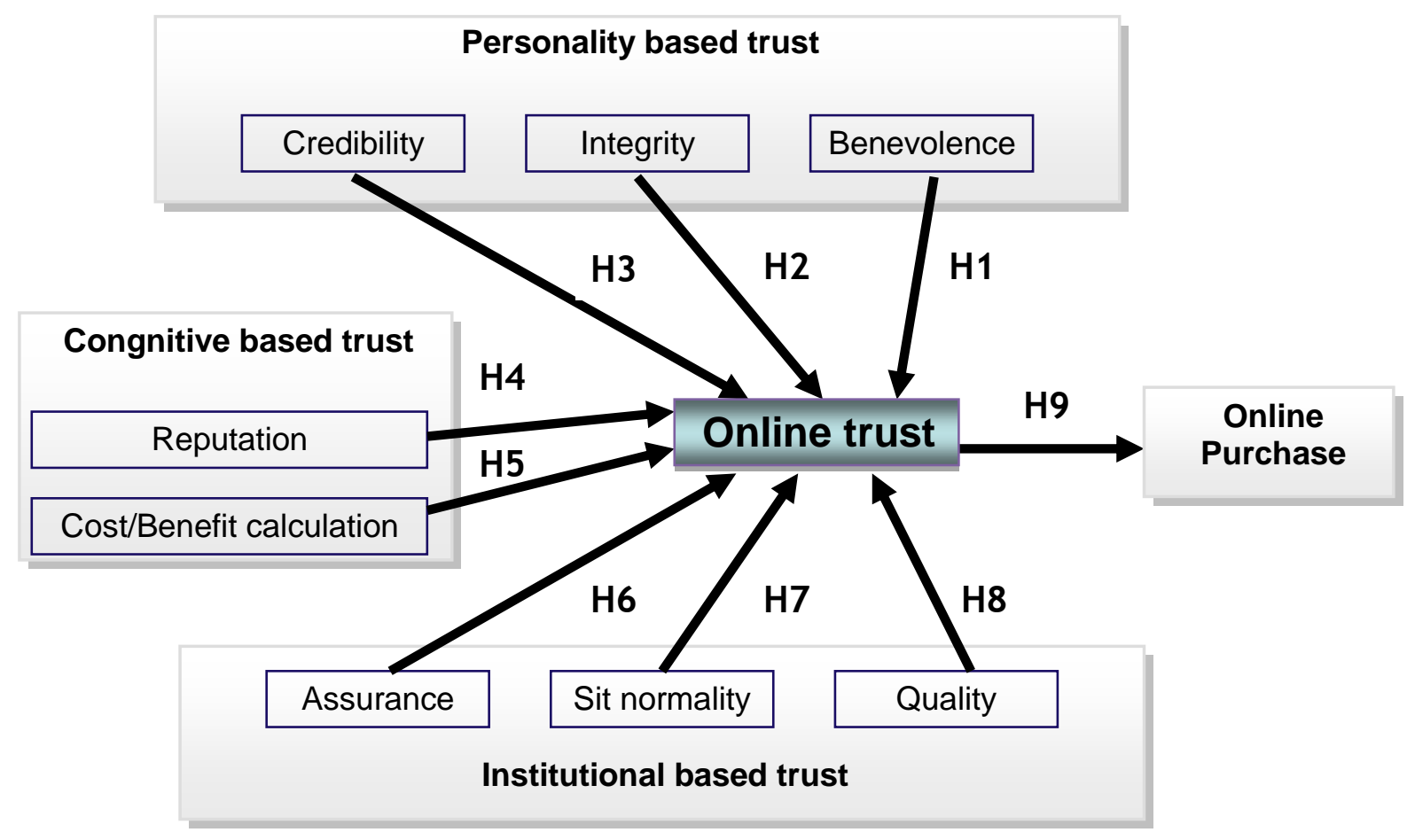

Figure 1: Determinants of online trust and their impacts on online purchase intention .

\section{Research Methodology}

A deductive approach was adopted and a survey was carried out to collect primary data. Measurement scales were adopted from prior research to ensure the content validity of the scales. The measurement of personality based trust (Credibility, integrity and benevolence) was adapted from the scale developed by $\mathrm{Li}$ et $a l$. , (2008). Besides the three dimensions attributed to the personality based trust, the two dimensions of cognitive trust (reputation and cost/benefit calculation) were measured respectively using the scales developed by Mcknight et al., (2002) and Gefen et al., (2003). The two first dimensions of institutional (structural assurance and situation normality) were measured by the scale developed by Gefen et al., (2003), the third dimension (quality) was measured by the scale of Mcknight et al., (2002). The scale of Chang and Chen, (2008) was used to measure online trust. Purchase intention was measured by the scale of Pavlou, (2003). Finally, the survey instrument used in this study consisted of a total of 34 items related to the ten constructs of the research model. The items were measured using a 5-point Likert-type scale for all constructs. The questionnaire is 
translated to Indonesian then back translated to English. Translation reliability was checked by two experts.

A snow ball sampling method was applied. The questionnaire was emailed to kaskus.co.id eshoppers who were asked to forward it to all their contacts that are also shopping on kaskus.co.id. Kaskus is the biggest merchant website in Indonesia with more than 3 million members (Kompas, 2011). Individuals sell new or used product to other individual in auction or "buy it now" system (Kompas, 2011). Indonesian customers form is a massive market with strong purchasing power (Guardian, 2011). Besides, Indonesia is an emergent market economy that is the most e-commerce ready according to Forrester Readiness Index (2013).

A pilot test was conducted and the wording of the items used in the questionnaire was slightly modified. 401 questionnaires were completed. Data collection was stopped once the proportion in the sample in terms of the main consumers' characteristics i.e. age and education were covered. These characteristics have been shown to be the most significant personal characteristics in online purchasing (Bigne, et al. 2005; Stafford et al. 2004; Susskind 2004). The characteristics of the sample are summarized in table 1:

\begin{tabular}{|l|l|}
\hline Characteristics & Percentages \\
\hline Gender & $\begin{array}{l}\text { Male: } 53.5 \% \\
\text { Female: } 46.5 \%\end{array}$ \\
\hline Age & $\begin{array}{l}{[19-25[\text { years old: } 45.3 \%} \\
{[26-35[\text { years old: } 23 \%} \\
{[36-45[\text { years old: } 20 \%}\end{array}$ \\
\hline Education & $\begin{array}{l}\text { Bachelor degree: } 29.8 \% \\
\text { College degree: } 27.8 \% \\
\text { Master degree: } 20 \% \\
\text { High school degree: } 14.5 \% \\
\text { Other education level : } 8.1 \%\end{array}$ \\
\hline
\end{tabular}

Table 1: Sample characteristics

\section{Data analysis and Results}

\section{Measurement model}

A confirmatory factor analysis using Amos 16 was conducted to test the reliability and the validity of the measures. Some common model-fit indices were used to assess the model overall goodness of fit (GFI, AGFI, RMR, RMSEA, NFI, TLI, CFI, Normed Khi-square). As 
shown in Table 2, the majority of the model-fit indices approach or exceed their respective common acceptance levels. So, we can conclude that the measurement model has an acceptable fit with the data collected. Therefore, we can evaluate the psychometric properties of the measurement model in terms of reliability, convergent validity and discriminant validity.

\begin{tabular}{|l|c|c|}
\hline \multicolumn{1}{|c|}{ Fit indices } & Recommended value & Measurement model \\
\hline GFI & $>0,9$ & 0,913 \\
\hline AGFI & $>0,9$ & 0,861 \\
\hline RMR & $<0,1$ & 0,065 \\
\hline RMSEA & $<0,08$ & 0,041 \\
\hline NFI & $>0,9$ & 0,939 \\
\hline TLI & $>0,9$ & 0,961 \\
\hline CFI & $>0,9$ & 0,974 \\
\hline Normed $\chi^{2}$ & $<5$ & 1,658 \\
\hline
\end{tabular}

Table 2: Measurement model goodness fit

Within confirmatory factor analysis, $\mathrm{T}$ test associated with each factorial contribution is much higher than 1.96, thus confirming the significance of the relationship of each indicator with the corresponding construct. Construct reliability, which reflects the internal consistency of the scale items measuring the same construct for the collected data (Straub, 1989), was assessed by computing Jöreskog's rho. As can be seen in Table II, the $\rho$ coefficient for each construct was above 0.716 , exceeding the common threshold value $(0.70)$ recommended by Fornell et Larker (1981). Thus, it is determined that the scale was reliable or internally consistent. The convergent validity of the constructs was estimated by calculating the rho of convergent validity $\left(\rho_{\mathrm{cv}}\right)$ which indicates the average variance extracted by the construct. The average extracted variances are for the majority above the recommended 0,5 level (Fornell et Larker, 1981) which mean that more than half of the variances observed in the items are accounted for by their hypothesized factors. However, purchase intention measure has a rho of convergent validity nearby the common 0.5 value (0.499). We can conclude to its acceptable validity. Thus, all factors in the measurement model have adequate reliability and convergent validity (Table 3). 


\begin{tabular}{|l|c|c|}
\hline \multicolumn{1}{|c|}{ Construct } & Reliability $(\rho$ of Jöreskog) & Convergent validity $\left(\rho_{\text {cv }}\right)$ \\
\hline Credibility (CRD) & 0,739 & 0,518 \\
\hline Integrity (INT) & 0,727 & 0,501 \\
\hline Benevolence (BNV) & 0,760 & 0,513 \\
\hline Reputation (RPT) & 0,725 & 0,568 \\
\hline Cost / Benefit calculation (CBC) & 0,721 & 0,570 \\
\hline Assurance (ASS) & 0,773 & 0,625 \\
\hline Sit. Normality (SN) & 0,739 & 0,527 \\
\hline Quality (QLT) & 0,834 & 0,668 \\
\hline Online trust (OLT) & 0,716 & 0,595 \\
\hline Purchase intention (PI) & 0,748 & 0,499 \\
\hline
\end{tabular}

Table 3: Measurement model reliability and convergent validity

To examine discriminant validity, the shared variances between factors is compared to the average variance extracted of the individual factors (Fornell et Larker, 1981). This analysis shows that the shared variance between factors is lower than the average variance extracted of the individual factors, confirming discriminant validity (Table 4).

\begin{tabular}{|l|l|l|l|l|l|l|l|l|l|l|}
\hline & CMP & INT & BNV & RPT & CBC & ASS & SN & QLT & OLT & PI \\
\hline CRD & 0,720 & & & & & & & & & \\
\hline INT & 0,681 & 0,708 & & & & & & & & \\
\hline BNV & 0,487 & 0,568 & 0,716 & & & & & & & \\
\hline RPT & 0,621 & 0,523 & 0,328 & 0,754 & & & & & & \\
\hline CBC & 0,702 & 0,559 & 0,505 & 0,618 & 0,755 & & & & & \\
\hline ASS & 0,363 & 0,366 & 0,336 & 0,436 & 0,476 & 0,791 & & & & \\
\hline SN & 0,489 & 0,483 & 0,486 & 0,530 & 0,584 & 0,493 & 0,726 & & & \\
\hline QLT & 0,580 & 0,710 & 0,692 & 0,400 & 0,546 & 0,332 & 0,511 & 0,817 & & \\
\hline OLT & 0,653 & 0,569 & 0,528 & 0,616 & 0,378 & 0,716 & 0,457 & 0,549 & 0,771 & \\
\hline PI & 0,643 & 0,499 & 0,458 & 0,470 & 0,546 & 0,393 & 0,453 & 0,548 & 0,686 & 0,706 \\
\hline
\end{tabular}

Table 4: Measurement model discriminant validity

In summary the measurement model shows adequate reliability, convergent validity and discriminant validity.

\section{Structural model}

A path analysis is conducted on the structural model in order to determine the direct and indirect effects of the research variables on purchase intention. Similarly to measurement model a set of indices is used to examine the structural model goodness fit (Table 5). In comparing fit indices with their corresponding recommended values, we conclude to an acceptable model fit. 


\begin{tabular}{|l|c|c|}
\hline \multicolumn{1}{|c|}{ Fit indices } & Recommended value & Measurement model \\
\hline GFI & $>0,9$ & 0,975 \\
\hline AGFI & $>0,9$ & 0,864 \\
\hline RMR & $<0,1$ & 0,043 \\
\hline RMSEA & $<0,08$ & 0,078 \\
\hline NFI & $>0,9$ & 0,979 \\
\hline TLI & $>0,9$ & 0,921 \\
\hline CFI & $>0,9$ & 0,982 \\
\hline Normed $\chi^{2}$ & $<5$ & 4,873 \\
\hline
\end{tabular}

Table 5: Structural model goodness fit

Thus, we can examine the path coefficients of the structural model. As shown in Table 6, standardised path coefficients, $\mathrm{t}$-values and variances explained for each significant equation of the hypothesized relations between constructs in the research model are presented.

As expected, the basis hypothesis $(\mathrm{H} 1, \mathrm{H} 2, \mathrm{H} 3, \mathrm{H} 4, \mathrm{H} 5$, and $\mathrm{H} 7)$ were supported, in that online trust is determined by personality based trust dimensions (Credibility, integrity and benevolence), cognitive based trust dimensions (reputation and cost / benefit calculation) and institutional based trust dimension (situation normality). The two institutional based trust dimensions (assurance and quality) seem to have no effect on online trust, so the hypothesis H6 and H8 were rejected. Online trust has a direct effect on purchase intention. Thus, we conclude to the validity of $\mathrm{H} 9$.

The explanation power of the model is $47 \%$, that is $47 \%$ of the variance of the purchase intention is explained by exogenous variables perceived risk and online trust which is determined for $74,6 \%$ by personality based trust dimensions (Credibility, integrity and benevolence), cognitive based trust dimensions (reputation and cost / benefit calculation) and institutional based trust dimension (situation normality).

\begin{tabular}{|l|c|c|c|c|}
\hline \multicolumn{1}{|c|}{ Relation } & Estimateur standardisé & t de Student & $\mathbf{p}$ & $\mathbf{R}^{\mathbf{2}}$ \\
\hline $\mathrm{CRD} \rightarrow$ OLT & 0,570 & 13,617 & 0,000 & \\
\hline $\mathrm{INT} \rightarrow$ OLT & 0,093 & 2,471 & 0,013 & \\
\hline $\mathrm{BNV} \rightarrow$ OLT & 0,163 & 4,949 & 0,000 & \multirow{2}{*}{0,746} \\
\hline $\mathrm{RPT} \rightarrow$ OLT & 0,134 & 3,767 & 0,000 & \\
\hline $\mathrm{CBC} \rightarrow$ OLT & 0,277 & 6,906 & 0,000 & \\
\hline $\mathrm{SN} \rightarrow$ OLT & 0,089 & 2,644 & 0,008 & \\
\hline OLT $\rightarrow$ PI & 0,689 & 18,822 & 0,000 & 0,470 \\
\hline
\end{tabular}

Table 6: Hypothesis testing results 


\section{Discussion and implications}

This research in line with previous findings (Isaac and Volle, 2008, Mcknight and al. (2002), Chouk and Perrien, (2004), Gefen, 2002, Doney and Cannon 1997) confirmed that online trust has three categories of antecedents: personality based dimensions - Credibility, integrity and benevolence-, cognitive based trust dimensions - reputation and cost/benefit calculationand institutional based trust dimension which is situation normality. However, assurance and quality dimensions related to institutional based trust (Corbitt et al 2003, Selnes 1998, Mcknight et al., 2003) were found to have insignificant effects on online trust. According to Bachmann and Inkpen farmework (2011), this finding can be justified as Indonesian consumers are at an advanced stage in their relationship with kaskus.co.id (searchcowboy, 2011). Besides, kaskus.co.id is the most popular e-commerce website (Kompas, 2011). Indonesian consumers are familiar with this website and make quick decisions to purchase products without worrying about assurance and quality of the website. In addition, kaskus.co.id has a good reputation with 3 million users in 2011 (Kompas, 2011) and is certificated by Alexa (Alexa, 2014, a).

We also found a direct effect between online trust and perceived risk on purchase intention. This result confirms previous authors' findings (Lu et al. 2005, Zhao et al., 2010, Kim et al., 2008, Chang and Chen, 2008). The more an individual trusts a website the bigger is his intention to purchase on this website.

The findings of this research have several managerial implications. Online brands have to develop integrity, Credibility and benevolence dimensions

These results provide valuable insights for professionals who should consider influencing online purchasing by promoting professional Credibility, benevolence and integrity. They should, certainly, create informative interfaces for potential cyber consumers, provide fast page downloads, short transaction times and frequent-user advantages for active users. Thus, practitioners should give an extra attention to prevent cyber consumers from consequently experiencing access difficulties, system crashes, drop outs, service delays and system failures which consequently decrease their trust belief. Moreover, professionals should reveal their integrity and credibility by respecting their promises, developing the features of security and privacy, and promoting their trustworthy brand. 


\section{Limitations and Future Research}

This empirical study has some limitations. Firstly, the study findings and implications are obtained from a single study that examined a particular website context. Thus, additional research, replicating the study on other website is needed to evaluate the validity of the investigated model and our findings. Second, this study was conducted with a snapshot research approach. This reduces the ability of this study to reflect on the temporal changes in the research constructs, especially when e-shopping experiences increase. Lewicki et al., (2006) showed that online trust is a dynamic concept that changes with consumers' experiences and through time Longitudinal evidence might enhance our understanding of the causality and effect relationships between antecedents of online trust and online purchase intention. Moreover, future research can focus on several types of websites to compare online trust determinants. Assurance and quality impact on online trust were shown to have no significant on online trust. It is interesting to investigate whether when familiarity of a website increases assurances and quality concerns decrease.

\section{References}

Ajzen, I., and Fishbein, M. (1980), Understanding Attitudes and Predicting Social Behavior. New Jersey: Prentice Hall.

Alexa.com, a, (Available at: http://www.alexa.com/products), [Accessed 25 February 2014].

Alexa.com, b (available at http://www.alexa.com/topsites/countries/ID ) [Accessed 25 February 2014].

Anderson, E., and Weitz, B. A. (1989), "Determinants of continuity in conventional industrial channel dyads", Marketing Science, 8/4, 310-324.

Bachmann R.and Inkpen A. (2011), "Understanding Institutional-based Trust Building Processes in Inter-organizational Relationships”, Organization Studies, vol. 32 no. 2 281-301

Baier, A. (1986), Trust and Antitrust. Chicago: Chicago: The University of Chicago Press.

Bhattacherjee A (2002), "Individual trust in online firms: scale development and initial test", Journal of Management Information Systems, Vol 19, №1.

Brown, H. G., Poole, M. S., and Rodgers, T. L. (2004), "Interpersonal traits, complementary, and trust in virtual collaboration", Journal of Management Information System, 20/4, 115137.

Buttler, J. K. Jr. (1991), “Towards understanding and measuring conditions of trust: evolution of a conditions of trust inventory", Journal of Management, 17/3, 643-663. 
Chang, H. H, and Chen, S. W. (2008), "The impact of online store environment cues on purchase intention: trust and perceived risk as a mediator", Online Information Review, 33/6, 818-841.

Chen S.C. and Dhillon G.S. (2003), "Interpreting Dimensions of Consumer Trust in ECommerce", Information Technology and Management, Volume 4, Issue 2-3, pp 303-318.

Chen, Y. H., and Barnes, S. (2007), "Initial trust and online buyer behaviour", Journal of Industrial Data and System, 107/1, 21-36.

Chouk I et Perrien J(2003), “ Les déterminants de la confiance du consommateur lors d'un achat sur un site marchand : proposition d'un cadre conceptuel préliminaire”, Actes du XIX Congrès International de l'AFM, Tunis 9 et 10 Mai.

Chouk I et Perrien J(2004), “ Consumer Trust towards an Unfamiliar Web Merchant”, Centre de recherche DMSP, Université Paris-DauphineCahier $\mathrm{n}^{\circ} 328$.

Corbitt, B. J, Thanasankit, T. Yi, H. (2003)," Trust and e-commerce: a study of consumer perceptions", Electronic commerce research and applications, 2, 203-215.

Doney, P. M., Cannon, J. P., and Mullen, M. R. (1998), "Understanding the Influence of National Culture on the Development of Trust", Academy of Management Review,23/3, 601620.

Doney, P.M.,Barry J.M. and Abratt R. (2007), “Trust determinants and outcomes in global B2B services”, European Journal of Marketing, Vol. 41 No. 9/10, pp. 1096-1116.

Donney , P. M., and Cannon, J. P. (1997), “An examination of the nature of trust in buyerseller relationship", Journal of Marketing, 61, 35-51.

Fletcher K.P. and Peters L.D. (1997) "Trust and direct marketing environments: A consumer perspective”, Journal of Marketing Management, Volume 13, Issue 6, pp. 523-539.

Forrester Readiness Index (2013), e-Commerce Global Study: A Quantitative Assessment Of The Global eCommerce Landscape, Available at:

http://www.forrester.com/Forrester+Readiness+Index+2013+eCommerce+Global+Study/fullt ext/-/E-RES103703?objectid=RES103703 accessed on 14/01/2014.

Ganesan, S. (1994), "Determinants of long term orientation in buyer-seller relationship", Journal of Marketing, 58/2, 1-19.

Gefen D(2002), "Reflections on the dimensions of trust and trust worthiness among online consumers", The DATA BASE for Advances Information Systems, ํ⒊

Gefen D, E Karahanna et DW Straub,( 2003), “ Trust and TAM in online shopping: an integrated model", MIS Quarterly, Vol 27, N¹.

Gefen D,(2000), "E-commerce : the role of familiarity and trust", Omega, Vol $28, \mathrm{~N}^{\circ} 6$. 
Grazioli, S., \& Jarvenpaa, S. (2000),“ Perils of Internet fraud: An empirical investigation of deception and trust with experienced Internet consumers. IEEE Transactions on Systems", Man, and Cybernetics, Part A: Systems and Humans, 30(4): 395-410.

Guardian. 2011. GDP projections from PWC: how China, India and Brazil will overtake the

West by 2050. [ONLINE] Available at: http://www.guardian.co.uk/news/datablog/2011/jan/07/gdp-projections-china-us-uk-brazil.

[Accessed 08 August 11].

Gulati Ranjay and Sytch Maxim (2008), "Does Familiarity Breed Trust? Revisiting the Antecedents of Trust", Managerial and Decision Economics, Manage. Decis. Econ. 29: 165190.

Hitt Michael A, Dacin M. Tina, Levitas Edward , Arregle Jean-Luc and Borza Anca (2000), "Partner Selection in Emerging and Developed Market Contexts: Resource-Based and Organizational Learning Perspectives", The Academy of Management Journal, Vol. 43, No. 3, pp 449-467.

Hofstede Gert Jan , Fritz Melanie, Canavari Maurizio, Oosterkamp Elsje, van Sprundel Gertjan (2010), "Towards a cross-cultural typology of trust in B2B food trade", British Food Journal, Vol. 112 Iss: 7, pp.671 - 687

Isaac Henri et Pierre Volle (2008), E-commerce: de la stratégie à la mise en auvre opérationnelle, Pearson Education .

Isaac Henri et Pierre Volle (2013), E-commerce: de la stratégie à la mise en ouvre opérationnelle, Pearson Education .

Indjikian, R. and Siegel, D.S.(2005), "The Impact of Investment in IT on Economic Performance: Implications for Developing Countries “, World Development, vol. ( 33) No: 5, pp. 681-700.

Janouri Faouzia et Gharbi Jamel Eddine(2008), “Affrontement entre le risque perçu et le capital marque dans la formation de la confiance dans un site marchand", www.esscpeap.net/conferences/marketing/2008-cp/Materiali / Paper/Fr/Janouri-Gharbi.pdf

Jarvenpaa, S. L., and Leidner, D. E. (1998), “Communication and trust in global virtual teams", Journal of Computer Mediated Communication, $3 / 4$.

Jarvenpaa, S. L., Tractinsky, N., and Saarinen, L. (1999), "Consumer Trust in an Internet Store: A Cross-Cultural Validation", Journal of Computer-Mediated Communication, 5/2.

Jiyeon, Kim and Forsythe, Sandra (2010), "Factors affecting adoption of product virtualization technology for online consumer electronics shopping”, International Journal of Retail \& Distribution Management, Volume 38, Number 3, pp. 190-204(15).

Johnson, D.S. (2007), “Achieving customer value from electronic channels through identity 
commitment, calculative commitment, and trust technology", Journal of Interactive

Marketing, Vol. 21 No. 4, pp. 2-22.

Kaynak Erdener, Tatoglu Ekrem and Kula Veysel (2005), "An analysis of the factors affecting the adoption of electronic commerce by SMEs: Evidence from an emerging market", International Marketing Review, Vol. 22 No. 6, pp. 623-640.

Kim, D. J., Ferrin, D. L., and Rao, H. R. (2008), “ A trust-based consumer decision-making model in electronic commerce: The role of trust, perceived risk, and their antecedents", Decission Support System, 44/2, 544-564.

Kompas.2011. KaskusGandeng Investor DalamNegeri. [ONLINE] Available at: http://tekno.kompas.com/read/2011/03/09/14530850/Kaskus.Gandeng.Investor.Dalam.Negeri . [Accessed 22 July 11].

Koufaris, M., and Hampton-Sosa, W. (2004), "The development of initial trust in an online company by new customers", Information Management, Vol. 41, No. 3, pp. 377-397.

Lewicki, R. J., and Bunker, B. B. (1995), Trust in relationships: a model of development and decline. 1st ed. San Fransisco: Josey Bass.

Lewicki, Roy J., Tomlinson, Edward C. and Gillespie Nicole (2006), "Models of Interpersonal Trust Development: Theoretical Approaches, Empirical Evidence, and Future Directions", Journal of Management December, vol. 32 no. 6, pp. 991-1022.

Li, X., Hess, T. J., and Valacich, J. S. (2008), "Why do we trust new technology? A study of initial", Strategic Information System, 17, 39-71.

Lim Nena , (2003)," Consumers' perceived risk: sources versus consequences”, Electronic Commerce Research and Applications, 2, 216-228.

Lohse, G. L., and Spiller, P. (1998), "Electronic Shopping.Communication of the ACM”, 41/7, 81-88.

Lu, M.-T., Liu, C.-H., Jing, J., Huang, L.J. (2005), "Internet banking: strategic responses to the accession of WTO by Chinese banks", Industrial Management \& Data Systems, 105/4, 429-42.

Matos, C.A. and Rossi, C.A. (2008), "Word-of-mouth communications in marketing: a metaanalytic review of the antecedents and moderators", Journal of the Academy of Marketing Science, Vol.36, No. 4, pp.578-596.

Mayer, R. C., Davis, J. H., and Schoorman, F. D. (1995), "An integrative model of organizational trust”, Academy of Management Review, 20/3, 709-734.

Mcknight, D. H, Choudhury, V., and Kacmar, C. (2002), "The impact of initial consumer trust on intentions to transact with a website: a trust building model", Journal of Strategic Information System, 11, 297-323. 
Mcknight, D. H. and Chervany, N. L. (2001), "What trust means in e-commerce customer relationships: an interdisciplinary conceptual typology", International Journal of Electronic Commerce, 6/2, 35-59.

Mcknight, D. H., Cummings, L. L., and Chervany, N. L. (1998), "Initial trust in new organizational relationships", Academy Management Review, 23/3, 479-490.

Meyerson, D, (1996), "Trust in organizations: frontiers of theory and research. California: Sage Publication.

Morgan R et Hunt S (1994), The commitment -trust theory of relationship marketing, Journal of Marketing, Vol 58.

Moorman, C., Deshpandé, R., \& Zaltman, G. (1993), "Factors affecting trust in market research relationships", Journal of Marketing, vol. 57, No. 1, pp. 81-101.

Parayitama, Satyanarayana, Dooleyb, Robert S. (2009), "The interplay between cognitiveand affective conflict and cognition- and affect-based trust in influencing decision outcomes", Journal of Business Research, Volume 62, Issue 8, August 2009, Pages 789-796.

Paul, D.L., and McDaniel, R.R. (2004), "A field study of the effect of interpersonal trust on virtual collaborative relationship performance", Management Information System Quarterly, 28/2, 183-227.

Pavlou, P. A. (2003), “ Consumer Acceptance of Electronic Commerce: Integrating Trust and Risk with the Technology Acceptance Model", International Journal of Electronic Commerce, 7/3, 101-134.

Powell, W. W. (1996), Trust Based Forms of Governance. 1st ed. California: Sage.

Quelch, J. A., and Klein, L. R. (1997), "Business-to-business market making on the Internet", International Marketing Review, 14/5, 345-361.

Robert Jr. L.P., Dennis A.R., and HungIndividual Y.C. (2009), “ Swift Trust and Knowledge-Based Trust in Face-to-Face and Virtual Team Members”, Journal of Management Information Systems, Vol. 26, No. 2, pp. 241-279

Rousseau, D. M., Sitkin, S. B., Burt, R. S., and Camerer, C. (1998), “ Not so different after all: a cross-discipline view of trust”, Journal of Academy of Management Review, 23/3, 393404.

Sabater Jordi and Sierra Carles (2005), "Review on computational trust and reputation models", Kluwer Academic Publishers. SabaterSierra.tex; 19/05/2005; 10:34; p.1.Available on (http://www.iiia.csic.es/ sierra/articles/2005/SabaterSierra.pdf) accessed in April 2013.

Schoenbachler, D.D. and Gordon, G.L. (2002), "Multi-channel shopping: understanding what drives channel choice", Journal of Consumer Marketing, Vol. 19 No. 1, pp. $42-53$. 
Searchcowboys (2011)“Indonesia's Largest Community: Kaskus" Accessed on the 1 April 2013 available at http://www.searchcowboys.com/research/1636

Selnes, F, (1998), “Antecedents and consequences of trust and satisfaction in buyer-seller relationships", European Journal of Marketing, 32/3, 305-322.

Shapiro, S.P., (1987), "The social control of impersonal trust", American Journal of S Schlosser AE,

Sheppard, B H and Sherman D.M. (1998) “ The grammars of trust: a model and general implications", Academy of Management Review, 23/3, 422-437.

Vance A.; Dit Cosaque Christopher Elie and Starub Detmar W. (2008), "Examining Trust in Information Technology Artifacts: The Effects of System Quality and Culture", Journal of Management Information Systems, Vol. 24, No. 4, pp. 73-100.

Wang Haiping (2010), "Review of studies on online consumer trust", Computational Intelligence and Natural Computing Proceedings (CINC), Second International Conference, Volume: 2, Digital Object Identifier: 10.1109/CINC.2010.5643778, Page(s): 97 - 100, IEEE Conference Publications.

Wang, Y.D., and Emurian, H.H. (2005), “An overview of online trust: concepts, elements and implications", Journal of Computers in Human Behavior, 21, 105-125.

Worldinternet Stats. (2011), Internet Usage Statistics The Internet Big Picture World Internet Users and Population Stats. [ONLINE] Available at: http://www.internetworldstats.com/stats.htm. [Accessed 14 August 11].

Yoon, S. J, (2002), “The antecedents consequences of trust in online purchase decision", Journal of Interactive Marketing, 16/2, 47-63.

Zhao, A. L., Lewis, N. K., Lloyd, S. H., and Ward, P. (2010), “Adoption of internet banking services in China: is it all about trust?", 28/1, 7-26.

Zucker, L.G., (1986), "Production of trust: Institutional sources of economic structure. Greenwich: CT. 